J. Dairy Sci. 92:491-498

doi:10.3168/jds.2008-1618

(C) American Dairy Science Association, 2009.

\title{
Immobilization of recombinant thermostable $\beta$-galactosidase from Bacillus stearothermophilus for lactose hydrolysis in milk
}

\author{
W. Chen, ${ }^{* 1}$ H. Chen, ${ }^{*}$ Y. Xia, ${ }^{*}$ J. Yang, ${ }^{*}$ J. Zhao, ${ }^{\star}$ F. Tian, ${ }^{*}$ H. P. Zhang,† and H. Zhang ${ }^{*}$ \\ *State Key Laboratory of Food Science and Technology, School of Food Science and Technology, Jiangnan University, Wuxi 214122, China \\ †Key Laboratory of Dairy Biotechnology and Engineering, Ministry of Education, Inner Mongolia Agricultural University, Huhhot, \\ Inner Mongolia 010018, P. R. China
}

\section{ABSTRACT}

A recombinant thermostable $\beta$-galactosidase from Bacillus stearothermophilus was immobilized onto chitosan using Tris(hydroxymethyl)phosphine (THP) and glutaraldehyde, and a packed bed reactor was utilized to hydrolyze lactose in milk. The thermostability and enzyme activity of THP-immobilized $\beta$-galactosidase during storage was superior to that of free and glutaraldehyde-immobilized enzymes. The THP-immobilized $\beta$-galactosidase showed greater relative activity in the presence of $\mathrm{Ca}^{2+}$ than the free enzyme and was stable during the storage at $4^{\circ} \mathrm{C}$ for $6 \mathrm{wk}$, whereas the free enzyme lost $31 \%$ of the initial activity under the same storage conditions. More than $80 \%$ of lactose hydrolysis in milk was achieved after $2 \mathrm{~h}$ of operation in the reactor. Therefore, THP-immobilized recombinant thermostable $\beta$-galactosidase from Bacillus stearothermophilus has the potential for application in the production of lactose-hydrolyzed milk.

Key words: $\beta$-galactosidase, thermostable, immobilization, lactose hydrolysis

\section{INTRODUCTION}

Lactose is the major carbohydrate present in milk and is not easily digested by a significant fraction of the global population (Panesar et al., 2006). Lactose ingested by lactose-intolerant people cannot be hydrolyzed owing to low levels of $\beta$-galactosidase in the jejunum; the passage of lactose to the large intestine can lead to tissue dehydration, poor calcium absorption, generation of hydrogen and carbon dioxide gases, diarrhea, bloating, flatulence, blanching, and cramps (Shukla, 1975).

$\beta$-Galactosidase (EC 3.2.1.23) is the gene product of the lacZ operon and an important industrial enzyme that is used in the hydrolysis of lactose in milk and

Received August 11, 2008.

Accepted October 22, 2008.

${ }^{1}$ Corresponding author: weichen@jiangnan.edu.cn whey to avoid the health and environmental problems posed by lactose (Ladero et al., 2005; Panesar et al., 2006). Although $\beta$-galactosidase has been found in a wide variety of sources including microorganisms, plants, and animals, the only commercially exploited sources are microorganisms (Agrawal et al., 1989). The maximum activity of $\beta$-galactosidase from fungi is generally at $\mathrm{pH} 3$ to 4 , whereas the optimum $\mathrm{pH}$ of $\beta$-galactosidase from yeasts and bacteria is typically in the range of $\mathrm{pH} 6$ to 7 . Because the normal $\mathrm{pH}$ of milk is around 6.5 to $6.6, \beta$-galactosidase from yeasts and bacteria is more suitable for application in the production of lactose-hydrolyzed milk than that from fungi (Ladero et al., 2005).

In the past decade, thermophilic bacteria have become an object of interest for the commercial production of $\beta$-galactosidase; the thermostable $\beta$-galactosidases generally have maximum activity at temperatures ranging from 70 to $90^{\circ} \mathrm{C}$ (Petzelbauer et al., 1999; Pessela et al., 2003; Cheng et al., 2006). When compared with mesophilic enzymes, the application of thermostable enzymes in the production of lactose-hydrolyzed products has significant advantages such as greater reaction velocity, reduced risk of microbial contamination, and longer enzyme half life under operational conditions (Hirata et al., 1985; Petzelbauer et al., 1999; Maciunska et al., 2000).

Because the thermostable $\beta$-galactosidase was reported to be only poorly produced in the original host, which was not suitable for large-scale production (Bruins et al., 2001; Kang et al., 2005), recombinant techniques have been applied in the production of thermostable $\beta$-galactosidase in a mesophilic host (Kang et al., 2005). In our previous research, a thermostable $\beta$-galactosidase from Bacillus stearothermophilus was cloned and successfully expressed in Bacillus subtilis WB600 (Chen et al., 2008). $\beta$-Galactosidase from $B$. subtilis expression system has potential application in dairy industry (Chen et al., 2002) because B. subtilis is considered a safe source (Mahoney, 2003).

Because application of immobilized enzyme in lactose hydrolysis could reduce the processing cost, ensure bet- 
ter control of the process, and eliminate the inhibitory effect of galactose on $\beta$-galactosidase, the immobilization technique was applied in the present study to the recombinant thermostable $\beta$-galactosidase. The objective of this study was to optimize the immobilization conditions of the thermostable $\beta$-galactosidase from the recombinant $B$. subtilis WB600/pMA5-bgaB and explore its application in lactose hydrolysis in milk.

\section{MATERIALS AND METHODS}

\section{Materials}

Chitosan was obtained from Golden-Shell Biochemical (Zhejiang, China). Tetrakis(hydroxymethyl) phosphonium chloride $(80 \%$, wt/vol) was obtained from Sunrise Science and Trade (Tianjin, China). Glutaraldehyde $(25 \%$, wt/vol) was obtained from Wulian Chemicals Co. Ltd. (Shanghai, China). O-nitrophenyl$\beta$-D-galactopyranoside (ONPG) was purchased from Sigma Chemicals (Sigma-Aldrich Corp., St. Louis, $\mathrm{MO}$ ). All other reagents were of analytical grade.

Escherichia coli TG1 was used as host strain for cloning and for the preparation of template plasmids. Bacillus stearothermophilus ATCC8005 was the donor of thermostable $\beta$-galactosidase coding sequence, and B. subtilis WB600 was used for expression of $\beta$-galactosidase. The plasmid pBSKII KS+ was the clone vector, and pMA5 was used for construction of the thermostable $\beta$-galactosidase expression plasmid in B. subtilis.

\section{Expression and Extraction of the Recombinant Thermostable $\beta$-Galactosidase}

The construction of expression vector and expression of the recombinant thermostable $\beta$-galactosidase was conducted according to the method described by Chen et al. (2008). The cells of B. subtilis WB600/ pMA5-bgaB were then suspended in $20 \mathrm{~m} M$ sodium phosphate buffer ( $\mathrm{pH}$ 7.0) and treated with sonication. The supernatant was collected after centrifugation at $4^{\circ} \mathrm{C}$ at $9,000 \times g$ for $10 \mathrm{~min}(\mathrm{~J} 2-21 \mathrm{M}$ centrifuge, Beckman Coulter Inc., Fullerton, CA). Subsequently, the solution was heated at $60^{\circ} \mathrm{C}$ for $50 \mathrm{~min}$ and centrifuged at $30,000 \times g$ for $30 \mathrm{~min}$, and $30 \%$ ammonium sulfate was added to the supernatant at $4^{\circ} \mathrm{C}$. After the centrifugation at $30,000 \times g$ for $30 \mathrm{~min}$, the pellet was discarded, and the supernatant was brought to $65 \%$ ammonium sulfate saturation and centrifuged at 30,000 $\times g$ for $30 \mathrm{~min}$ again. The pellet was dissolved in 20 $\mathrm{m} M$ sodium phosphate $(\mathrm{pH} 7.5)$, dialyzed at $4^{\circ} \mathrm{C}$ for 24 $\mathrm{h}$, and lyophilized.

\section{Immobilization of $\beta$-Galactosidase and Optimization of Immobilization Conditions}

The enzyme immobilization was prepared by reaction of soluble $\beta$-galactosidase with chitosan activated by the coupling agent Tris(hydroxymethyl)phosphine (THP) and glutaraldehyde according to the method described by Oswald et al. (1998). According to preliminary results, $\beta$-galactosidase was dissolved in $0.1 \mathrm{M}$ sodium phosphate buffer ( $\mathrm{pH} 7.0$ ) and mixed with $0.63 \mathrm{mg} /$ $\mathrm{mL}$ THP-activated and $0.25 \%$ glutaraldehyde-activated chitosan solution to reach $100 \mathrm{U} / \mathrm{mL}$, respectively. The suspensions of the enzyme with THP and glutaraldehyde were shaken at room temperature for 10 min and 1 $\mathrm{h}$, respectively. Then, they were washed free of excess of coupling agents with distilled water and a $1 \mathrm{M} \mathrm{NaCl}$ solution, respectively. Experiments were performed under the following conditions to optimize the immobilization procedure: at 5 immobilization durations of $15,30,60$, 120, and $180 \mathrm{~min}$; at 3 immobilization temperatures of 30,40 , and $50^{\circ} \mathrm{C}$; and at $4 \mathrm{pH}$ values of $6.0,6.5,7.0$, and 7.5.

\section{Effect of Temperature, $\mathrm{pH}$, and Metal lons on Enzyme Activity}

The effect of temperature on the activity of free and immobilized $\beta$-galactosidase was determined with a 5 -h incubation at 60,65 , and $70^{\circ} \mathrm{C}(\mathrm{pH} 7.0)$ before analysis. The effect of $\mathrm{pH}$ ( $\mathrm{pH} 6.0$ to 8.0) on the relative enzyme activity of free and immobilized $\beta$-galactosidase was determined with a 5 -h incubation at $70^{\circ} \mathrm{C}$ before analysis. The effects of univalent cations $\mathrm{K}^{+}$and $\mathrm{Na}^{+}$, and divalent cations $\mathrm{Mn}^{2+}, \mathrm{Mg}^{2+}, \mathrm{Fe}^{2+}, \mathrm{Zn}^{2+}$, and $\mathrm{Ca}^{2+}(10$ $\mathrm{m} M$ ) on the enzyme activity of free and immobilized $\beta$-galactosidase was determined after the incubation at $25^{\circ} \mathrm{C}$ for $20 \mathrm{~min}$ in potassium phosphate buffer (200 $\mathrm{m} M, \mathrm{pH}$ 6.5) with various reagents.

\section{Reusability and Storage Stability of Immobilized Enzyme}

The reusability of the immobilized enzyme was evaluated by incubation with ONPG 9 times at $70^{\circ} \mathrm{C}$ for $10 \mathrm{~min}$ (between each successive use, the immobilized enzyme was washed with distilled water). The storage stabilities of the free and immobilized enzymes were evaluated during storage at $4^{\circ} \mathrm{C}$ for 6 wk (in 0.1 $M$ potassium phosphate buffer, $\mathrm{pH}$ 7.0). The samples were analyzed for the residual activity every week. The thermostability of $\beta$-galactosidase was measured after 5 $\mathrm{h}$ of incubation at 60,65 , and $70^{\circ} \mathrm{C}$. 


\section{Enzyme Assay}

Enzyme activity was measured spectrophotometrically according to the method described by Xia et al. (2005). One unit of enzyme activity is defined as the amount of enzyme that hydrolyzes 1 mole of substrate ONPG per minute. During the optimization of immobilization conditions, the relative activity of the immobilized enzyme was measured by regarding the activity of free enzyme as $100 \%$. During the characterization of immobilized enzyme, relative activity was calculated by regarding the maximum activity at given conditions as $100 \%$.

\section{Hydrolysis of Lactose in Milk by THP-Immobilized $\beta$-Galactosidase}

Hydrolysis of lactose in milk was investigated using a packed bed reactor $(2.6 \mathrm{~cm} \times 5.5 \mathrm{~cm})$. The THPimmobilized enzyme was loaded into the reactor, and milk flowed through the column $\left(70^{\circ} \mathrm{C}\right)$ at a constant flow rate. Three different flow rates of $0.8,1.3$, and $2 \mathrm{~mL} / \mathrm{min}$ were applied. Samples were taken for the analysis at the outlet of the reactor and the hydrolysis of lactose was estimated according to the procedure described by Zhou et al. (2003).

\section{Statistical Analysis}

All experiments and analysis were done in triplicate. Data analysis was performed using the SAS (version 8.0, SAS Inst. Inc. Cary, NC), and ANOVA was performed. Mean values were compared using the Duncan multiple range test and considered significantly different when $P<0.05$.

\section{RESULTS AND DISCUSSION}

\section{Optimization of Immobilization Temperature, pH, and Duration}

The effect of the immobilization temperature on activity of the THP-immobilized and glutaraldehydeimmobilized $\beta$-galactosidases is shown in Table 1. The THP-immobilized $\beta$-galactosidase displayed greater activity than the glutaraldehyde-immobilized $\beta$-galactosidase, which was consistent with previous research (Oswald et al., 1998). The THP-immobilized and glutaraldehyde-immobilized $\beta$-galactosidase activity ranged between 84.3 and $86.5 \%$ and 46.9 and $50.3 \%$, respectively. The immobilization temperature showed no significant effect on enzyme activity $(P>0.05)$. Therefore, all subsequent immobilizations were carried out at room temperature. The effect of $\mathrm{pH}$ on enzyme activity
Table 1. Effect of immobilization temperature on activity of THP ${ }^{1}$ immobilized and glutaraldehyde-immobilized $\beta$-galactosidases from Bacillus stearothermophilus ${ }^{2}$

\begin{tabular}{lcc}
\hline & \multicolumn{2}{c}{ Relative activity (\%) } \\
\cline { 2 - 3 } Temperature $\left({ }^{\circ} \mathrm{C}\right)$ & $\begin{array}{c}\text { THP-immobilized } \\
\text { enzyme }\end{array}$ & $\begin{array}{c}\text { Glutaraldehyde- } \\
\text { immobilized enzyme }\end{array}$ \\
\hline 30 & $86.5 \pm 2.1^{\mathrm{a}}$ & $50.3 \pm 2.2^{\mathrm{a}}$ \\
40 & $85.3 \pm 2.6^{\mathrm{a}}$ & $50.6 \pm 1.9^{\mathrm{a}}$ \\
50 & $84.3 \pm 1.7^{\mathrm{a}}$ & $47.9 \pm 2.2^{\mathrm{a}}$ \\
\hline
\end{tabular}

${ }^{a}$ Means within a column with different superscripts are significantly different $(P<0.05)$.

${ }^{1} \mathrm{THP}=$ Tris(hydroxymethyl)phosphine.

${ }^{2}$ Values are means $\pm \mathrm{SD} ; \mathrm{n}=3$.

is shown in Table 2. Both the THP-immobilized and glutaraldehyde-immobilized $\beta$-galactosidases showed their maximum activities between $\mathrm{pH} 6.5$ and 7.0. The effect of immobilization duration on enzyme activity is shown in Table 3. There was no significant change in the activity of THP-immobilized enzyme within the immobilization duration of $180 \mathrm{~min}(P>0.05)$, whereas the glutaraldehyde-immobilized enzyme maintained the greatest relative activity at the immobilization duration between 60 and 120 min.

Oswald et al. (1998) reported that glutaraldehyde formed $\mathrm{C}=\mathrm{N}$ Schiff base bonds in the coupling reaction, whereas THP reacted with amino compounds via a Mannich-type condensation reaction. Although the mechanisms of the coupling reactions of THP and glutaraldehyde are different, immobilization temperature showed no significant effect on relative activity of the immobilized enzymes in both cases, which indicated that the covalent attachment of $\beta$-galactosidase with both glutaraldehyde and THP were not heat sensitive.

\section{Characterization of Immobilized Galactosidase}

Effect of Temperature. The effect of temperature on the activity of the free and immobilized enzymes

Table 2. Effect of immobilization $\mathrm{pH}$ on activity of $\mathrm{THP}^{1}$-immobilized and glutaraldehyde-immobilized $\beta$-galactosidases from Bacillus stearothermophilus ${ }^{2}$

\begin{tabular}{lcc}
\hline & \multicolumn{2}{c}{ Relative activity (\%) } \\
\cline { 2 - 3 } $\begin{array}{l}\text { Immobilization } \\
\text { pH values }\end{array}$ & $\begin{array}{c}\text { THP-immobilized } \\
\text { enzyme }\end{array}$ & $\begin{array}{c}\text { Glutaraldehyde- } \\
\text { immobilized enzyme }\end{array}$ \\
\hline 6.0 & $75.6 \pm 1.9^{\mathrm{b}}$ & $39.2 \pm 2.1^{\mathrm{c}}$ \\
6.5 & $87.2 \pm 1.3^{\mathrm{a}}$ & $47.3 \pm 1.5^{\mathrm{a}}$ \\
7.0 & $86.9 \pm 2.3^{\mathrm{a}}$ & $47.8 \pm 1.2^{\mathrm{a}}$ \\
7.5 & $76.7 \pm 1.5^{\mathrm{b}}$ & $42.9 \pm 0.7^{\mathrm{b}}$ \\
\hline
\end{tabular}

${ }^{a-c}$ Means within a column with different superscripts are significantly different $(P<0.05)$ by Duncan's multiple range test.

${ }^{1} \mathrm{THP}=$ Tris(hydroxymethyl)phosphine.

${ }^{2}$ Values are means $\pm \mathrm{SD} ; \mathrm{n}=3$. 


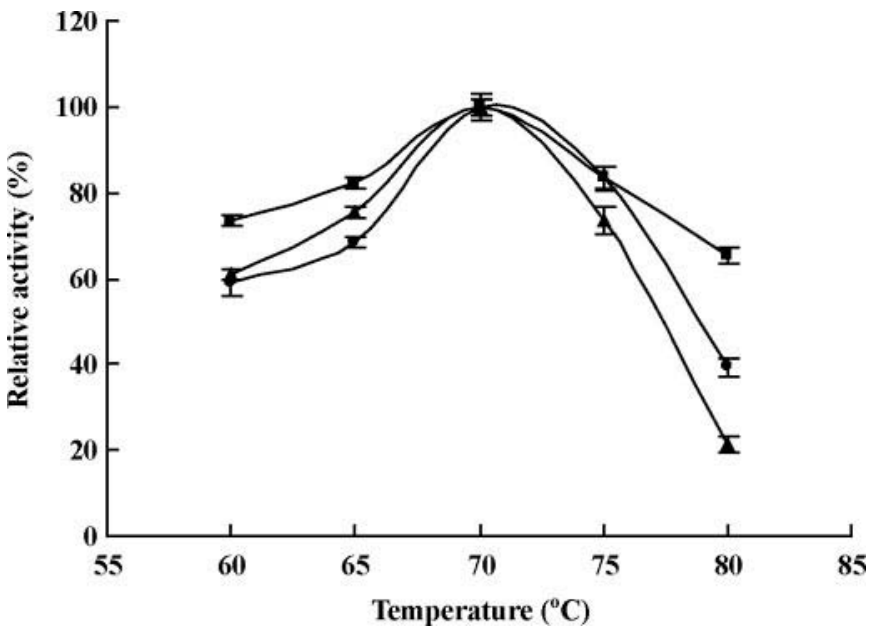

Figure 1. Effects of temperature on relative enzyme activity of free and immobilized enzymes. - Tris(hydroxymethyl)phosphine (THP)-immobilized enzyme; $\boldsymbol{\Delta}=$ glutaraldehyde-immobilized enzyme; $\boldsymbol{0}$ = free enzyme.

is shown in Figure 1. The optimum temperatures for both the free and immobilized enzymes were achieved at $70^{\circ} \mathrm{C}$. At $80^{\circ} \mathrm{C}$ the THP-immobilized enzyme showed $65 \%$ of its maximal activity, whereas the free and the glutaraldehyde-immobilized enzymes only showed 21 and $38 \%$ of their maximal activities, respectively.

Enzyme activity is dependent on the temperature, and there is an optimum temperature of the enzymatic reaction above which the activity decreases due to denaturation of the enzyme. Our results indicated that although the immobilization process had no effect on the optimal reaction temperature of $\beta$-galactosidase, the THP-immobilized enzyme generally showed increased temperature tolerance. Previous research was rather controversial regarding the influence of immobilization on the optimum temperature of enzymes. Batra et al. (2005) reported that the $\beta$-galactosidase immobilized by DEAE-cellulose provoked a shift in the optimal temperature from 65 to $70^{\circ} \mathrm{C}$. However, others reported that immobilization with THP did not result in dramatic changes in the optimum temperature of the enzymes because THP reacted with nonessential $\mathrm{NH}_{2}$ groups, which minimized the enzyme inactivation (Oswald et al. 1998). Our results also proved that THP did not affect the optimum temperature of the enzyme.

Effect of $\boldsymbol{p H}$. The effect of $\mathrm{pH}$ on the activity of the free and immobilized enzymes is shown in Figure 2 . Compared with the free enzyme, the immobilization of $\beta$-galactosidase with both THP and glutaraldehyde broadened the $\mathrm{pH}$-activity profiles of the enzymes, and the immobilized enzymes had greater activity at the acidic and alkaline conditions. The free enzyme reached maximum activity at $\mathrm{pH} 7.0$, and the optimal $\mathrm{pH}$ of
Table 3. Effect of immobilization duration on activity of glutaraldehydeimmobilized and $\mathrm{THP}^{1}$-immobilized $\beta$-galactosidase from Bacillus stearothermophilus ${ }^{2}$

\begin{tabular}{lcc}
\hline & \multicolumn{2}{c}{ Relative activity (\%) } \\
\cline { 2 - 3 } $\begin{array}{l}\text { Immobilization } \\
\text { time (min) }\end{array}$ & $\begin{array}{c}\text { THP-immobilized } \\
\text { enzyme }\end{array}$ & $\begin{array}{c}\text { Glutaraldehyde- } \\
\text { immobilized enzyme }\end{array}$ \\
\hline 15 & $85.8 \pm 2.9$ & $35.5 \pm 0.9^{\mathrm{d}}$ \\
30 & $85.2 \pm 1.1$ & $41.7 \pm 2.1^{\mathrm{c}}$ \\
60 & $85.9 \pm 3.2$ & $50.9 \pm 3.0^{\mathrm{a}}$ \\
120 & $85.3 \pm 0.7$ & $49.9 \pm 2.5^{\mathrm{a}}$ \\
180 & $84.9 \pm 1.5$ & $45.2 \pm 1.1^{\mathrm{b}}$ \\
\hline
\end{tabular}

${ }^{\mathrm{a}-\mathrm{d}}$ Means within a column with different superscripts are significantly different $(P<0.05)$ by Duncan's multiple range test.

${ }^{1} \mathrm{THP}=$ Tris(hydroxymethyl)phosphine.

${ }^{2}$ Values are means $\pm \mathrm{SD} ; \mathrm{n}=3$.

the 2 immobilized enzymes shifted to $\mathrm{pH} 6.8$, which is suitable for lactose hydrolysis in milk (with a normal $\mathrm{pH}$ of 6.5 to 6.6 ). Previous research showed that immobilization of enzyme generally resulted in no or little influence on the maximum $\mathrm{pH}$ of the enzyme (Stanley et al., 1975; Martino et al., 1996), which was consistent with our results.

Effect of Metal Ions. Univalent cations $\left(\mathrm{Na}^{+}\right.$ and $\mathrm{K}^{+}$) and the divalent cation $\mathrm{Mg}^{2+}$ did not show significant influence on the activity of the free and immobilized enzymes (Table 4). Other divalent cations greatly inhibited the activity of the free enzyme, with only $29.2,0.1,17.7$, and $56.4 \%$ of the relative activity remaining in the presence of $\mathrm{Ca}^{2+}, \mathrm{Fe}^{2+}, \mathrm{Zn}^{2+}$, and $\mathrm{Mn}^{2+}$, respectively. However, the enzyme immobilized with THP kept $100 \%$ of its activity in the presence of $\mathrm{Ca}^{2+}$ and $\mathrm{Mn}^{2+}$, and 84.7 and $69.3 \%$ in the presence of $\mathrm{Fe}^{2+}$ and $\mathrm{Zn}^{2+}$, respectively.

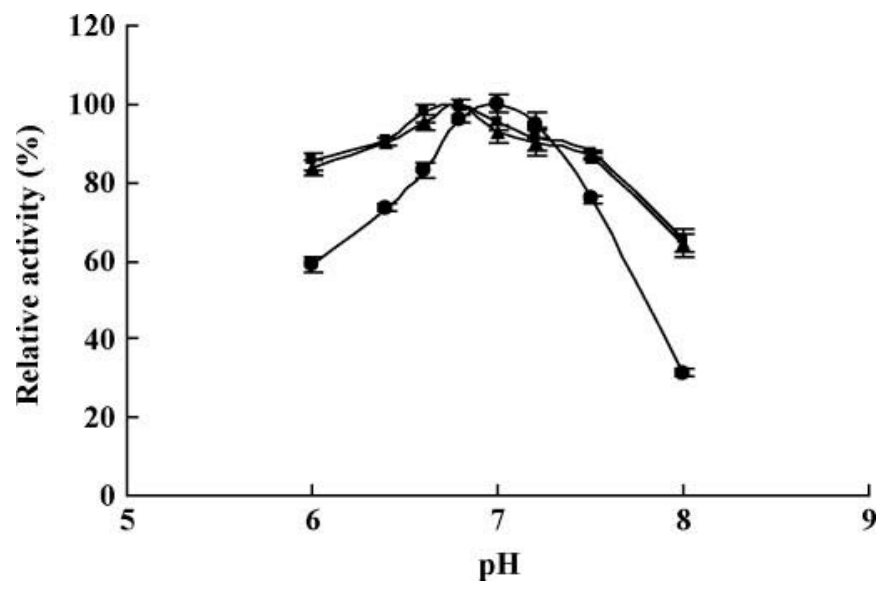

Figure 2. Effects of $\mathrm{pH}$ on relative enzyme activity of free and immobilized enzymes. $=$ Tris(hydroxymethyl)phosphine (THP)immobilized enzyme; $\boldsymbol{\Delta}=$ glutaraldehyde-immobilized enzyme; $\bullet=$ free enzyme. 


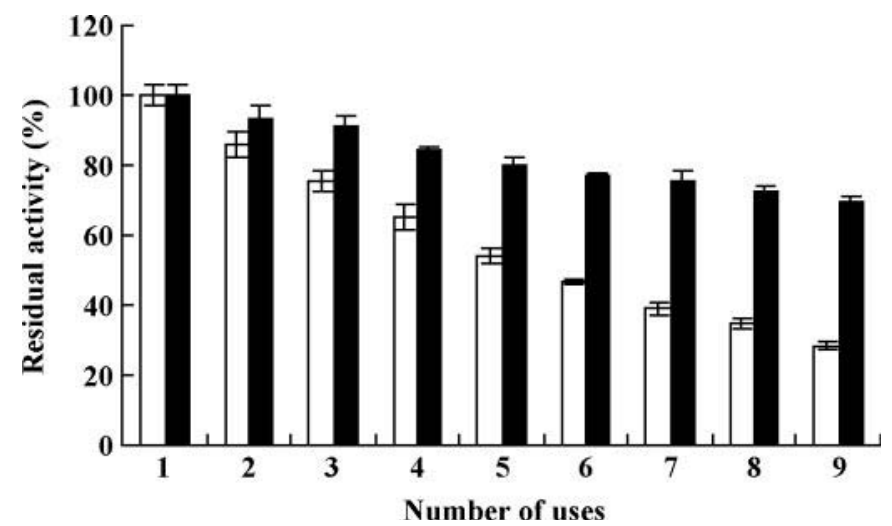

Figure 3. Effects of reuse times on residual activity of immobilized enzymes. The white and black bars represent the glutaraldehyde- and tris(hydroxymethyl)phosphine (THP)-immobilized enzymes, respectively.

Because $\mathrm{Ca}^{2+}$ inhibited the activity of the free enzyme but did not inhibit the activity of the THP-immobilized enzyme, the THP-immobilized enzyme should therefore be suitable the application in dairy products that contain relatively high levels of $\mathrm{Ca}^{2+}$.

The functional form of $\beta$-galactosidase is a tetramer of 4 identical subunits (Appel et al., 1965), which contains 4 catalytic sites that show no cooperativity or allosteric effectors. Metal ions reportedly play important roles in catalysis of $\beta$-galactosidase, and multiple metal-binding sites have been identified in $\beta$-galactosidase (Juers et al., 2000). The presence of $\mathrm{Mg}^{2+}$ was believed to be essential for the maximum activity (Juers et al., 2001), but no previous reports have shown that $\mathrm{Ca}^{2+}$ could boost the activity of THP-immobilized $\beta$-galactosidase.

Reusability. Unlike free enzymes, immobilized enzymes can be easily separated from product solutions and reused (Katchalski-Katzir, 1993), which is important for economical use of an enzyme. Figure 3 shows the activity of immobilized enzymes after repeated use.

Table 4. Effect of metal ions on activity of free and $\mathrm{THP}^{1}$-immobilized $\beta$-galactosidases from Bacillus stearothermophilus ${ }^{2}$

\begin{tabular}{lcc}
\hline & \multicolumn{2}{c}{ Relative activity (\%) } \\
\cline { 2 - 3 } Metal ion & Free enzyme & THP-immobilized enzyme \\
\hline $\mathrm{Na}^{+}$ & $104 \pm 3.1$ & $108 \pm 2.9$ \\
$\mathrm{~K}^{+}$ & $104 \pm 2.9$ & $108 \pm 2.7$ \\
$\mathrm{Mg}^{2+}$ & $102 \pm 3.6$ & $104 \pm 3.6$ \\
$\mathrm{Ca}^{2+}$ & $29.2 \pm 2.1^{\mathrm{b}}$ & $100 \pm 3.2^{\mathrm{a}}$ \\
$\mathrm{Fe}^{2+}$ & $0.1 \pm 0.02^{\mathrm{b}}$ & $84.7 \pm 3.1^{\mathrm{a}}$ \\
$\mathrm{Zn}^{2+}$ & $17.7 \pm 1.1^{\mathrm{b}}$ & $69.3 \pm 2.2^{\mathrm{a}}$ \\
$\mathrm{Mn}^{2+}$ & $56.4 \pm 2.6^{\mathrm{b}}$ & $119 \pm 3.6^{\mathrm{a}}$ \\
\hline
\end{tabular}

a,b Means within a row with different superscripts are significantly different $(P<0.05)$ by Duncan's multiple range test.

${ }^{1} \mathrm{THP}=$ Tris(hydroxymethyl)phosphine.

${ }^{2}$ Values are means $\pm \mathrm{SD} ; \mathrm{n}=3$.
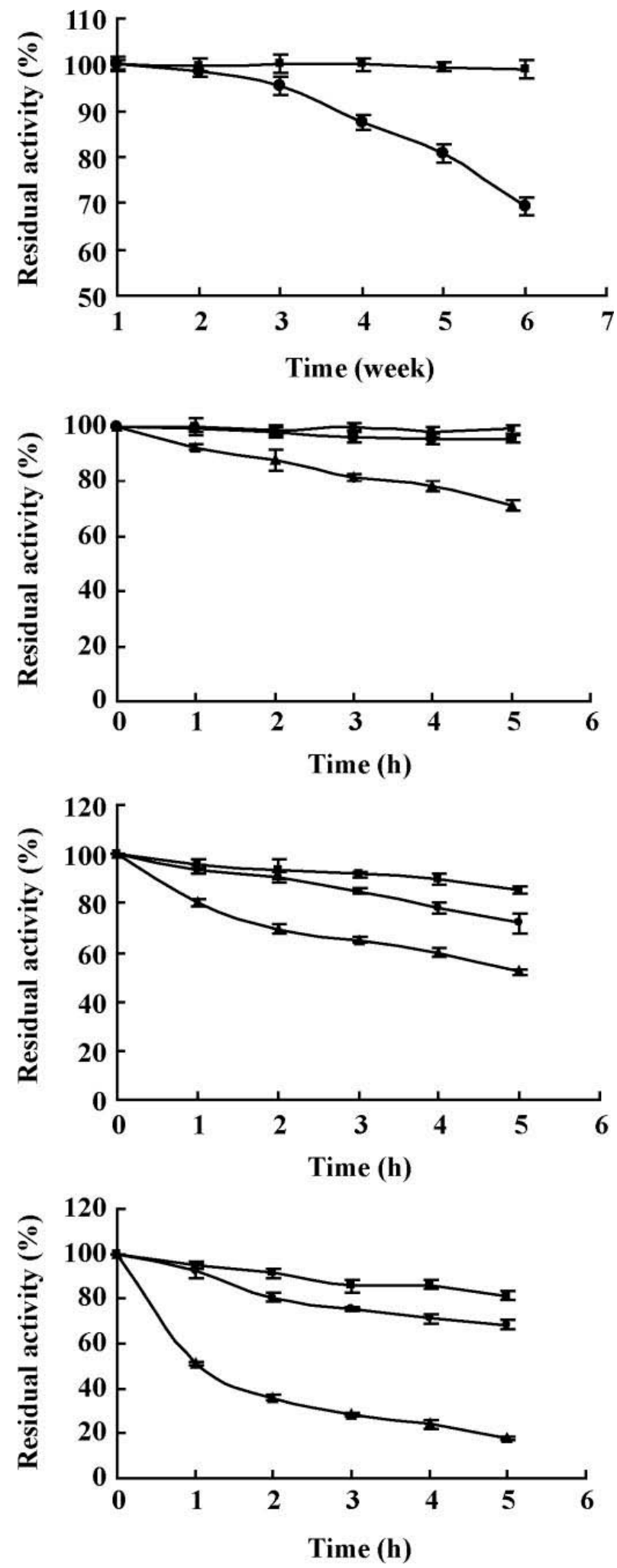

Figure 4. Storage and thermostability of free and immobilized enzymes: Storage at A) $4^{\circ} \mathrm{C}$; B) $60^{\circ} \mathrm{C}$; C) $65^{\circ} \mathrm{C}$; and D) $70^{\circ} \mathrm{C}$ (A to D from top to bottom). $\mathbf{\square}=$ Tris(hydroxymethyl)phosphine (THP)immobilized enzyme; $\boldsymbol{\Delta}=$ glutaraldehyde-immobilized enzyme; $\bullet=$ free enzyme. 
After the ninth repeated use, the THP-immobilized enzyme retained $70 \%$ of its activity, whereas the glutaraldehyde-immobilized enzyme lost $72 \%$ of its activity. Oswald et al. (1998) studied the properties of immobilized $\beta$-glucosidase and reported that 8 cycles of use of glutaraldehyde-immobilized $\beta$-glucosidase led to a loss of $88 \%$ of the overall activity, whereas THPimmobilized $\beta$-glucosidase lost only $32 \%$ of its activity, which was consistent with our results.

Storage Stability and Thermal Stability. Enzyme stability strongly depends on storage temperature and the immobilization process. The storage stabilities of the free and immobilized enzymes during the storage at $4^{\circ} \mathrm{C}$ for 6 wk are presented in Figure 4A. The THPimmobilized enzyme was stable during the 6 -wk storage at $4^{\circ} \mathrm{C}$, whereas the free enzyme lost approximately $31 \%$ of its activity under the same storage conditions. Thus, the THP-immobilized enzyme exhibits better storage stability than that of the free enzyme.

The free and THP-immobilized enzymes were stable during the 5 -h storage at $60^{\circ} \mathrm{C}$, whereas the residual activity of glutaraldehyde-immobilized enzyme decreased over time (Figure $4 \mathrm{~B}$ ). At $65^{\circ} \mathrm{C}$ the activity of the glutaraldehyde-immobilized enzyme declined rapidly and only kept $52 \%$ of its residual activity after the 5-h incubation (Figure 4C). The THP-immobilized enzyme provided an obvious advantage in thermostability over the free enzyme and glutaraldehyde-immobilized enzymes. After the incubation for $2 \mathrm{~h}$ at $70^{\circ} \mathrm{C}$, the THP-immobilized enzyme retained $90 \%$ of its activity, and the free enzyme and glutaraldehyde-immobilized enzyme retained only 80 and $36 \%$ of their activities, respectively (Figure 4D). Because the optimum temperature for thermostable $\beta$-galactosidase was $70^{\circ} \mathrm{C}$ and because in commercial production immobilized enzymes are generally used repetitively, good thermostability of the immobilized $\beta$-galactosidase around the optimum temperature is essential for its application in lactose hydrolysis in milk. Our results showed that THPimmobilized $\beta$-galactosidase had good thermostability, making it suitable for application in lactose hydrolysis.

It was reported that the particle sizes of the chitosan carriers obtained from different immobilization techniques varied, and macro-, micro-, and nanosized chitosan particles could be obtained by precipitation, cross-linking, and ionic gelation methods, respectively (Biro et al., 2008). Biro et al. (2008) showed that the highest activity was showed by the biocatalyst immobilized on nanoparticles, and $\beta$-galactosidase fixed on macro- and microspheres exhibited excellent storage stability in aqueous solution, with no more than $5 \%$ loss of activity after $3 \mathrm{wk}$ of storage at $4^{\circ} \mathrm{C}$ and $\mathrm{pH}$ 7.0. In the present study, although both THP and glutaraldehyde were covalently attached to chitosan, THP- immobilized $\beta$-glucosidase showed better storage and thermostability than the glutaraldehyde-immobilized enzyme. The poor thermal stability of glutaraldehydeimmobilized enzymes may be attributed to the hydrolysis of the $\mathrm{C}=\mathrm{N}$ Schiff base bonds formed in the coupling reaction at high temperatures (Oswald et al., 1998). The enhanced thermostability of the THP-immobilized enzyme might have resulted from the encumbrance effects of tri-dimensional structure of the carrier and the good thermostability of the $-\mathrm{P}-\mathrm{CH}_{2}-\mathrm{N}$ - bond formed between the enzyme and the THP-activated support (Oswald et al., 1998). Therefore, THP-immobilized $\beta$-galactosidase is more suitable for application in the commercial production of lactose-hydrolyzed milk than glutaraldehyde-immobilized enzyme.

Reusability and thermal stability are the major advantages of application of thermostable immobilized enzymes in lactose hydrolysis, which will greatly reduce the cost of downstream processing and risk of microbial contamination.

\section{Lactose Hydrolysis in Milk}

Lactose hydrolysis by THP-immobilized enzyme was performed in a packed bed reactor at $70^{\circ} \mathrm{C}$ as described above and the results are shown in Figure 5. The initial lactose content of the whole milk was 4.68 weight percent and more than $60 \%$ of lactose was hydrolyzed after $100 \mathrm{~min}$ of the operation with a flow rate of 0.8 $\mathrm{mL} / \mathrm{min}$. When the flow rate increased to $1.3 \mathrm{~mL} / \mathrm{min}$, lactose hydrolysis rate increased and more than $80 \%$ of lactose was hydrolyzed after $2 \mathrm{~h}$ of operation. However, when the flow rate was further increased to $2 \mathrm{~mL} / \mathrm{min}$, lactose hydrolysis rate decreased (data not shown). A linear hydrolysis rate was observed within the first 40 min of the reaction regardless of the flow rate, and the hydrolysis rate slowed down afterwards.

The effect of the flow rate on the hydrolysis rate might be due to the effect of the fluid distribution on lactose hydrolysis in the reactor ( $\mathrm{Li}$ et al., 2007). In fact, not all the enzyme active sites in the reactor could intimately stay in contact with the lactose molecules in milk. Therefore, the flow rate of the milk through the reactor affected the extent of lactose hydrolysis in milk.

It was reported that $\beta$-galactosidase from Thermus sp. T2 was competitively inhibited by galactose and noncompetitively inhibited by glucose, and the inhibitions were strongly reduced by immobilization on Sepabeads (Pessela et al., 2003). Novalin et al. (2005) established a hollow fiber membrane reactor process for enzymatic lactose hydrolysis with mesophilic $\beta$-galactosidase and achieved a conversion rate of $78.11 \%$. Roy and Gupta (2002) immobilized Lactozym, a commercially available 


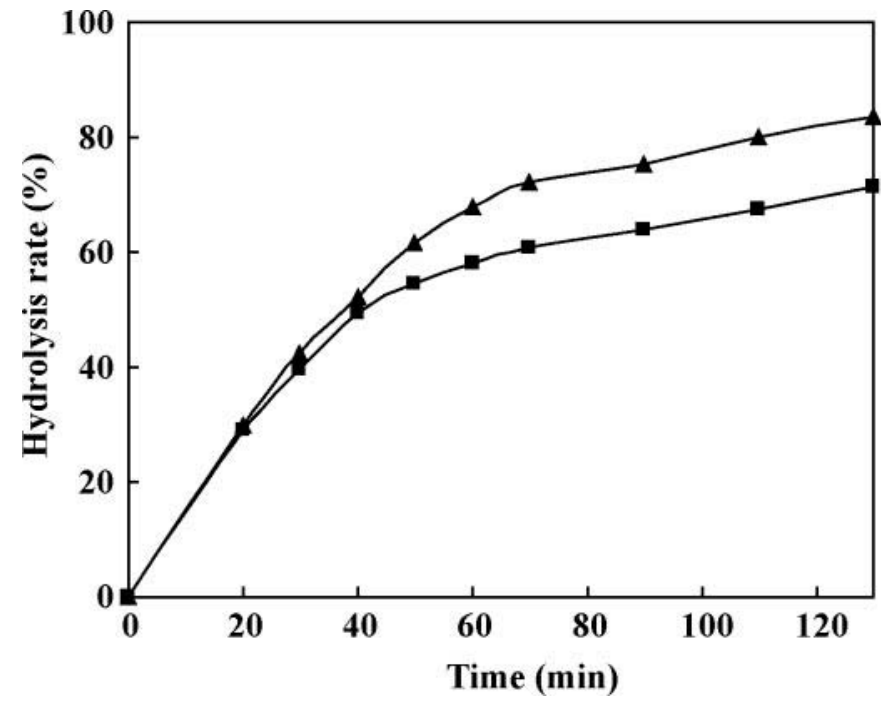

Figure 5. Hydrolysis of lactose in milk by Tris(hydroxymethyl) phosphine (THP)-immobilized $\beta$-galactosidase in a packed bed reactor at $70^{\circ} \mathrm{C}(\boldsymbol{\square})$ at a flow rate of $0.8 \mathrm{~mL} / \mathrm{min},(\boldsymbol{\Lambda})$ at a flow rate of 1.3 $\mathrm{mL} / \mathrm{min}$.

$\beta$-galactosidase, on cellulose beads and obtained a $90 \%$ conversion of whey lactose in $5 \mathrm{~h}$ with a fluidized bed reactor.

Application of immobilized mesophilic enzymes in lactose hydrolysis in the food industry have been shown as early as the 1970s, but currently there are no commercially available immobilized thermostable $\beta$-galactosidases (Roy and Gupta, 2002). Thermostable $\beta$-galactosidase provided unique advantages over the mesophilic enzyme with greater reaction velocity and reduced risk of microbial contamination, and the application of immobilization and recombinant techniques could further reduce the processing cost and time on separation of enzyme from the substrate. In the present study a lactose hydrolysis rate greater than $80 \%$ was achieved after $2 \mathrm{~h}$ of operation in the packed bed reactor with THP-immobilized recombinant thermostable $\beta$-galactosidase. However, more research is needed to further increase the hydrolysis rate and explore the application of THP-immobilized recombinant thermostable $\beta$-galactosidase on an industry production scale. In conclusion, THP-immobilized recombinant thermostable $\beta$-galactosidase has great industry application potential in the production of lactose hydrolyzed milk.

\section{CONCLUSIONS}

The THP-immobilized recombinant thermostable $\beta$-galactosidase showed superior enzyme activity, reusability, thermostability, and storage stability compared with the free and glutaraldehyde-immobilized enzymes, which could greatly reduce the cost of downstream pro- cessing and risk of microbial contamination. The THPimmobilized $\beta$-galactosidase showed greater relative activity in the presence of $\mathrm{Ca}^{2+}$ than the free enzyme and was stable during storage at $4^{\circ} \mathrm{C}$ for $6 \mathrm{wk}$, whereas the free enzyme lost $31 \%$ of the initial activity under the same storage conditions. Hydrolysis of lactose in milk was conducted with THP-immobilized $\beta$-galactosidase, and more than $80 \%$ of lactose hydrolysis was achieved after $2 \mathrm{~h}$ of operation in a packed-bed reactor. Therefore, THP-immobilized recombinant thermostable $\beta$-galactosidase has great application potential in the production of lactose-hydrolyzed milk.

\section{ACKNOWLEDGMENTS}

This work was financially supported by National Natural Science Foundation of China (No. 30670065), 111 Project and Innovative Research Team in University (IRT0627), and the National High Technology Research and Development Program of China (No. 2007AA10Z316 and 2007AA100604).

\section{REFERENCES}

Agrawal, S., S. K. Garg, and S. M. Dutta. 1989. Microbial $\beta$-galactosidase: Production, properties and industrial applications-A review. Indian J. Dairy Sci. 42:251-262.

Appel, S. H., D. H. Alpers, and G. M. Tomkins. 1965. Multiple molecular forms of $\beta$-galactosidase. J. Mol. Biol. 11:12-22.

Batra, N., J. Singh, A. Joshi, and R. C. Sobti. 2005. Improved properties of Bacillus coagulans $\beta$-galactosidase through immobilization. Eng. Life Sci. 5:581-584.

Biro, E., A. S. Nemeth, C. Sisak, T. Feczko, and J. Gyenis. 2008 Preparation of chitosan particles suitable for enzyme immobilization. J. Biochem. Biophys. Methods 70:1240-1246.

Bruins, M. E., A. E. Janssen, and R. M. Boom. 2001. Thermozymes and their applications: A review of recent literature and patents. Appl. Biochem. Biotechnol. 90:155-186.

Chen, W., H. Chen, Y. Xia, J. Zhao, F. Tian, and H. Zhang. 2008. Production, purification, and characterization of a potential thermostable galactosidase for milk lactose hydrolysis from Bacillus stearothermophilus. J. Dairy Sci. 91:1751-1758.

Chen, W., H. Zhang, and X. L. Ding. 2002. Study on properties of thermostable $\beta$-galactosidase and hydrolysis of lactose in milk. China Dairy Ind. 30:15-18.

Cheng, T. C., K. J. Duan, and D. C. Sheu. 2006. Application of Tris(hydroxymethyl)phosphineas a coupling agentfor $\beta$-galactosidase immobilized on chitosan to produce galactooligosaccharides. J. Chem. Technol. Biotechnol. 81:233-236.

Hirata, H., S. Negoro, and H. Okada. 1985. High production of thermostable $\beta$-galactosidase of Bacillus stearothermophilus in Bacillus subtilis. Appl. Environ. Microbiol. 49:1547-1549.

Juers, D. H., T. D. Heightman, A. Vasella, J. D. McCarter, L. Mackenzie, S. G. Withers, and B. W. Matthews. 2001. A structural view of the action of Escherichia coli (lacZ) beta-galactosidase. Biochemistry 40:14781-14794.

Juers, D. H., R. H. Jacobson, D. Wigley, X. J. Zhang, R. E. Huber, D. E. Tronrud, and B. W. Matthews. 2000. High resolution refinement of beta-galactosidase in a new crystal form reveals multiple metal-binding sites and provides a structural basis for alpha-complementation. Protein Sci. 9:1685-1699.

Kang, S. K., K. K. Cho, J. K. Ahn, J. D. Bok, S. H. Kang, J. H. Woo, H. G. Lee, S. K. You, and Y. J. Choi. 2005. Three forms of thermostable lactose-hydrolase from Thermus sp. IB-21: Cloning, 
expression, and enzyme characterization. J. Biotechnol. 116:337346.

Katchalski-Katzir, E. 1993. Immobilized enzymes-learning from past successes and failures. Trends Biotechnol. 11:471-478.

Ladero, M., R. Ferrero, A. Vian, A. Santos, and F. Garcia-Ochoa. 2005. Kinetic modelling of the thermal and $\mathrm{pH}$ inactivation of a thermostable $\beta$-galactosidase from Thermus sp. strain T2. Enzyme Microb. Technol. 37:505-513.

Li, X. M., Q. Z. K. Zhou, and X. D. Chen. 2007. Pilot-scale lactose hydrolysis using beta-galactosidase immobilized on cotton fabric. Chem. Eng. Process. 46:497-500.

Maciunska, J., M. Scibisz, and J. Synowiecki. 2000. Stability and properties of a thermostable $\beta$-galactosidase immobilized on chitin. J. Food Biochem. 24:299-310.

Mahoney, R. R. 2003. $\beta$-galactosidase. Pages 823-828 in Handbook of Food Enzymology. J. R. Whitaker, ed. Marcel Dekker, New York, NY

Martino, A., M. Durante, P. G. Pifferi, G. Spagna, and G. Bianchi 1996. Immobilization of fl-glucosidase from a commercial preparation. Part 1.A: comparative study of natural supports. Process Biochem. 3:281-285.

Novalin, S., W. Neuhaus, and K. D. Kulbe. 2005. A new innovative process to produce lactose-reduced skim milk. J. Biotechnol. 119:212-218.

Oswald, P. R., R. A. Evans, W. Henderson, R. M. Daniel, and C. J. Fee. 1998. Properties of a thermostable $\beta$-galactosidase immobilized using tris(hydroxymethyl)phosphine as a highly effective coupling agent. Enzyme Microb. Technol. 23:14-19.
Panesar, P. S., R. Panesar, R. S. Singh, J. F. Kennedy, and H. Kumar 2006. Microbial production, immobilization and applications of $\beta$-D-galactosidase. J. Chem. Technol. Biotechnol. 81:530-543.

Pessela, B. C., C. Mateo, M. Fuentes, A. Vian, J. L. Garcia, A. V. Carrascosa, J. M. Guisán, and R. Fernández-Lafuente. 2003. The immobilization of a thermophilic $\beta$-galactosidase on Sepabeads supports decreases product inhibition: Complete hydrolysis of lactose in dairy products. Enzyme Microb. Technol. 33:199-205.

Petzelbauer, I., B. Hidetzeky, D. Haltrich, and K. D. Kulbe. 1999 Development of an ultra-high-temperature process for the enzymatic hydrolysis of lactose. I. The properties of two thermostable betaglycosidases. Biotechnol. Bioeng. 64:322-332.

Roy, I., and M. N. Gupta. 2003. Lactose hydrolysis by Lactozym ${ }^{\mathrm{TM}}$ immobilized on cellulose beads in batch and fluidized bed modes. Process Biochem. 39:325-332.

Shukla, T. P. 1975. Beta-galactosidase technology: A solution to the lactose problem. CRC Crit. Rev. Food Technol. 5:325-356.

Stanley, W. L., G. G. Watters, B. Chan, and J. M. Mercer. 1975. Lactose and other enzymes bound to chitin with glutaraldehyde. Biotechnol. Bioeng. 17:315-326.

Xia, Y., W. Chen, X. Y. Fu, H. Zhang, S. Yang, and X. L. Ding. 2005. Construction of an integrative food-grade expression system for Bacillus subtilis. Food Res. Int. 38:251-256.

Zhou, Q. Z., X. D. Chen, and X. Li. 2003. Kinetics of lactose hydrolysis by Beta-galactosidase of Kluyveromyces lactis immobilized on cotton fabric. Biotechnol. Bioeng. 81:127-133. 